\title{
PERENCANAAN GAPURA DI KAWASAN MCK TERPADU JL. TIRTARONA RT 03, RW 07, KELURAHAN TLOGOMAS, KECAMATAN LOWOKWARU, KOTA MALANG
}

\author{
Agustina Nurul Hidayati ${ }^{1}$, Mohammad Reza ${ }^{2}$, Fardiah Qonita ${ }^{3}$, \\ M. Dafa Murtado ${ }^{4}$, Andhyka Putra B ${ }^{5}$, Utas Satrio Pangintan ${ }^{6}$, \\ Evan $^{7}$ \\ ${ }^{1234567)}$ Program Studi Perencanaan Wilayah dan Kota \\ ${ }^{1234567)}$ Institut Teknologi Nasional Malang \\ 3)1724029.fardiahq@gmail.com
}

\begin{abstract}
The gate as an identity in an area can be a center for depicting partnerships between the Tirtarona Foundation as a tour manager caring for changes in the Integrated Sanitation area with the National Institute of Technology Malang as a university in the field of technology that can enable to introduce the seriousness of the National Institute of Technology in developing technology in seeking the vision of the National Institute of Technology Malang to the community. For this reason, in the community service program we hope to provide a choice of the concept of the gate that will be built in the Integrated Sanitation Area.
\end{abstract}

Keywords: Gate, Identity, Integrated Sanitation Area

\section{Pendahuluan}

\section{Latar Belakang}

Institut Teknologi Nasional Malang memiliki visi yaitu sebagai lembaga Pendidikan yang unggul dalam pengembangan ilmu pengetahuan, teknologi terapan dan seni, serta peningkatan kualitas sumber daya manusia yang berbudi luhur, berjiwa kewirausahaan, professional dan berwawasan global. Untuk dapat menyebarkan serta menindaklanjuti visi Institut Teknologi Nasional Malang secara lebih luas tentunya, diperlukan upaya nyata diantaranya dengan membangun hubungan kemitraan dengan Yayasan Tirtarona sebagai pengelola wisata peduli perubahan iklim serta kawasan MCK Terpadu yang berlokasi di Jl. Tirtarona RT 03, RW 07, Kelurahan Tlogomas.

Gapura sebagai identitas pada suatu wilayah dapat menjadi sarana dalam menunjukkan adanya kemitraan antara Yayasan Tirtarona sebagai pengelola wisata peduli perubahan iklim serta kawasan MCK Terpadu dengan Institut Teknologi Nasional Malang sebagai perguruan tinggi dibidang teknologi sehingga diharapkan dapat mengenalkan keseriusan Institut Teknologi Nasional Malang dalam pengembangan teknologi sebagaimana visi Institut Teknologi Nasional Malang pada masyarakat secara umum.

\section{Tujuan Penelitian}

Tujuan dari penelitian ini adalah untuk memberi bantuan perancangan Teknik kepada masyarakat Jl. Tirtarona RT 03, RW 07, Kelurahan Tlogomas, Kecamatan Lowokwaru, Kota Malang
Diharapkan penelitian ini dapat Hasil dari kegitan penelitian ini berupa rancangan bangunan tugu yang akan digunakan sebagai acuan atau pedoman dalam pelaksanaan pembangunan nantinya.

\section{Tinjauan Pustaka}

\section{Perancangan}

Perancangan adalah suatu kreasi untuk mendapatkan suatu hasil akhir dengan mengambil suatu tindakan yang jelas, atau suatu kreasi atas sesuatu yang mempunyai kenyataan fisik. Dalam bidang teknik, hal ini masih menyangkut suatu proses dimana prinsip-prinsip ilmiah dan alat-alat teknik seperti matamatikan komputer dan bahasa dipakai, dalam menghasilkan suatu rancangan yang kalau dilaksanakan akan memenuhi kebutuhan manusia. (Ratodi , 2015)

\section{Citra Lokasi}

Citra Lokasi terdiri dari tiga rangkaian komponen yang berbeda yang dibutuhkan diantaranya yaitu: cognitive image, affective image dan unique image. Cognitive Image, terdiri dari kualitas pengalaman yang didapat oleh para wisatawan, atraksi wisata yang ada di suatu destinasi, lingkungan tersebut, dan tradisi budaya dari destinasi tersebut. Affective Image, terdiri dari atraksi yang menyenangkan, membangkitkan, santai, dan menarik ketika di suatu destinasi. Unique image, terdiri dari lingkungan alam, kemenarikan suatu destinasi dan atraksi lokal yang ada di destinasi tersebut. (Fatimah , 2019)

\section{Manfaat Penelitian}

Gapura 
Pada hakekatnya gapura/gerbang merupakan pintu. Pintu-pintu tersebut tidak sekadar bidang kosong untuk keluar-masuk tetapi diberi pelengkap. Bingkai pintunya dibuat dengan ukuran besar sehingga pintu ini merupakan bangunan tersendiri. Sehingga bentuk disekitar pintu ini nampak lebih menonjol daripada pagar keliling. Keseluruhan bangunan yang melingkupi pintu inilah yang dimaksud gapura. (Purnama , 2013)

\section{Metode Penelitian}

\section{Lingkup Studi dan Wilayah Penelitian}

Lingkup wilayah penelitian ini adalah masyarakat Jl. Tirtarona RT 03, RW 07, Kelurahan Tlogomas, Kecamatan Lowokwaru, Kota Malang.

\section{Metode Penelitian dan Analisis Data}

Metode analisa yang sesuai di sini adalah manganalisa bentuk dasar gapura terhadap arah view di sekitarnya. Tahapan selanjutnya adalah meletakkan tanaman yang sesuai untuk memperkuat keberadaan dan bentukan gapura yang ada. Tahapan terakhir adalah mengoptimalkan hasil desain yang diperoleh dengan olahan taman kecil di sekitar gapura. Pola pembentukan gapura yang ada menunjukkan bahwa ada beberapa faktor tambahan yang perlu diperhatikan yakni jarak gapura terhadap obyek lainnya di sekitarnya. Semakin besar jarak gapura terhadap obyek di sekitarnya, maka akan semakin mudah menjadikan gapura sebagai identitas yang kuat. Pemikiran pentingnya mempertimbangkan faktor manusia saat seseorang melintasi suatu obyek seperti saat dengan kebutuhan tertentu adalah sebagaimana juga diutarakan oleh Allen dan kawan-kawan (2014) serta Zhu dan Shi (Wardhana, Idrasprasti, \& Fitriana, 2017). kemudian dikompilasikan dengan teori maupun data lainnya. Pengidentifikasian faktor-faktor yang berperan dalam pengembangan potensi kepariwisataan dilakukan dengan cara menentukan faktor-faktor berdasarkan pada faktor pengaruh dari teori dan faktor pengaruh lokal. Penentuan strategi pengembangan menggunakan metode IPA (Importance Performance Analysis) yang menghasilkan tipe kuadran strategi pengembangan.

\section{Hasil dan Pembahasan}

Dari hasil pelaksanaan penelitian di lapangan, diperoleh data bahwa masyarakat Jl. Tirtarona RT 03, RW 07, Kelurahan Tlogomas, Kecamatan Lowokwaru, Kota Malang sudah memiliki gapura sebelumnya, namun seiring dengan pesatnya laju pembangunan sehingga keberadaan gapura lama tertutup oleh pertokoan.

Ditambah dengan adanya bentuk kerjasama antara Institut Teknologi Nasional, Malang dengan Yayasan Tirtarona sebagai pengelola MCK Terpadu yang terletak di masyarakat Jl. Tirtarona RT 03, RW 07, Kelurahan Tlogomas, Kecamatan Lowokwaru,
Kota Malang sehingga diperlukan adanya gapura yang representatifsebagai penanda keberadaan pengelola MCK Terpadu yang terletak di masyarakat Jl. Tirtarona RT 03, RW 07, Kelurahan Tlogomas, Kecamatan Lowokwaru, Kota Malang.

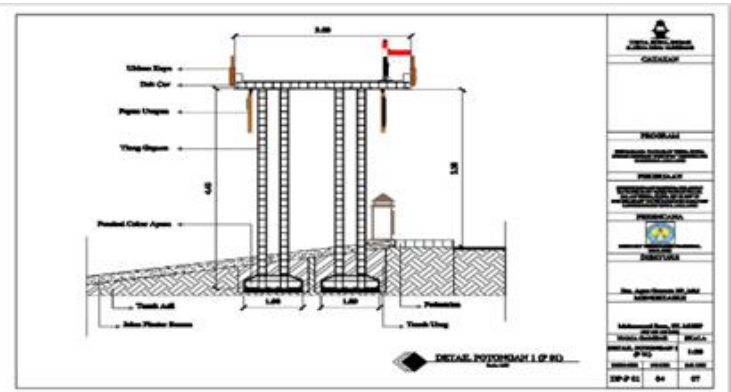

Gambar 1. Rancang Bangun Gapura Yayasan Tirtaron

Melalui proses penelitian ini diperoleh beberapa poin dalam membuat rancangan desain, antara lain yaitu:

1. Lokasi gapura dimajukan sejajar dengan pertokoan

2. Gapura didesain dengan filosofi yang merepresentasikan nilai - nilai filosofi kawasan MCK Terpadu yang terdapat di Jl. Tirtarona RT 03, rw 07 Kelurahan Tlogomas, Kecamatan Lowokwaru, Kota Malang

3. Konsep yang diajukan diupayakan mampu menjadi media mengenalkan adanya bentuk Kerjasama antara Institut Teknologi Nasional Malang dengan Yayasan Tirtarona dalam pengembangan teknologi pengolahan limbah rumah tangga.

Adapun filosofi yang terkandung dalam desain gapura yaitu sebagai berikut

1. Warna putih yang melatarbelakangi tulisan "Selamat Datang di Kawasan MCK Terpadu" melambangkan kemurnian

2. Tulisan "Selamat Datang di Kawasan MCK Terpadu" berwarna hijau melambangkan pertumbuhan dimana kawasan MCK Terpadu mendukung kelestarian lingkungan secara berkelanjutan

3. Warna Abu - abu pada salah satu sisi gapura sebagai simbol kestabilan

4. 4 garis layer berwarna abu - abu pada salah satu sisi gapura melambangkan keseimbangan unsur alam

5. 3 garis layer berwarna orange pada salah satu sisi gapura melambangkan filosofi nista, madya dan utama tahapan pada perkembangan yang dianut oleh masyarakat jawa yang dibalut dengan kreativitas yang dilambangkan dengan warna orange

Detail pada material konstruksi menggunakan material beton dengan besi tulangan diameter 16 $\mathrm{mm}$ dan $12 \mathrm{~mm}$ dan pondasi berukuran $1 \mathrm{~m} \mathrm{x} 1 \mathrm{~m} \mathrm{x}$ $0,4 \mathrm{~m}$ dan tinggi gapura $4,12 \mathrm{~m}$. Detail pada material atap gapura menggunakan besi tulangan diameter 
Perencanaan Gapura di Kawasan MCK Terpadu Jl. Tirtarona RT 03, RW 07, Kelurahan Tlogomas, Kecamatan Lowokwaru, Kota Malang

$12 \mathrm{~mm}$ dengan ketebalan $0,20 \mathrm{~m}$ dan panjang 3 meter.

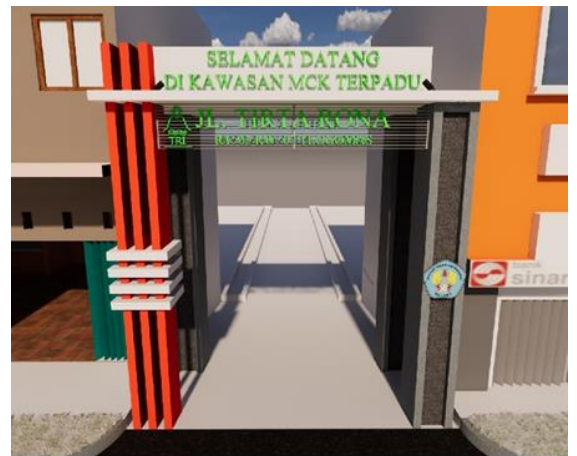

Gambar 2. Detail Konstruksi Rancang Bangun Gapura

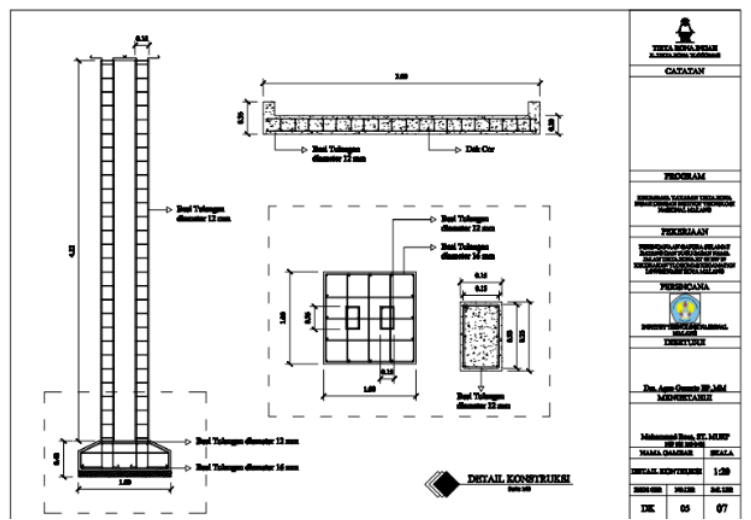

Gambar 2. Detail Konstruksi Tiang dan Atap Gapura

\section{Kesimpulan}

Kawasan MCK Terpadu yang terletak di Jl. Tirtarona RT 03, RW 07, Kelurahan Tlogomas, Kecamatan Lowokwaru, Kota Malang memiliki potensi citra lokasi yang perlu diperkuat dengan adanya gapura sebagai penanda kawasan. Disamping menjadi batas penanda kawasan, keberadaan gapura juga merupakan representasi daya Tarik yang ada di kawasan MCK Terpadu

\section{Daftar Pustaka}

1) Fatimah , S. (2019). Analisis Pengaruh Citra Destinasi dan Lokasi Terhadap Minat Berkunjung Kembali . Majalah Ilmiah Bahari Jogja , 27-40.

2) Purnama , I. (2013). Peneraoan Material Bata Pada Gapura/ Gerbang Masuk Bangunan. Seminar Nasional Scan (pp. 129-135). Cirebon : Prodi Arsitektur Sekolah Tinggi Teknologi Cirebon .

3) Ratodi , M. (2015). Metode Perancangan Arsitektur. Surabaya: Universitar Islam Negri Sunan Ampel .

4) Triastianti , R. D., Nasirudin , Sukirno , \& Warsiyah. (2017). Konservasi Sumber Daya Air dan Lingkungan Melalui Kearifan Lokal di Desa Margodadi Kecamatan Seyegen Kabupaten Sleman Yogyakarta . Kawistara, 207-314

5) Wardhana, M., Idrasprasti, A., \& Fitriana, R. N. (2017). Kajian Desain Gapura dengan Konsep
Green Design sebagai Upaya Pembentuk Identitas suatu Lingkungan . Jurnal Desain Interior , 21-26. 